\title{
Maïté Maskens, Cheminer avec Dieu : pentecôtisme et migrations à Bruxelles
}

Bruxelles, Éditions de l'Université de Bruxelles, coll. « Religion, laïcité et société », 2013, 220 p.

\section{Régis Dericquebourg}

\section{(2) OpenEdition}

\section{Journals}

Édition électronique

URL : http://journals.openedition.org/assr/26497

DOI : $10.4000 /$ assr. 26497

ISSN : 1777-5825

Éditeur

Éditions de l'EHESS

Édition imprimée

Date de publication : 31 décembre 2014

Pagination : 246

ISBN : 978-2-7132-2467-6

ISSN : 0335-5985

Référence électronique

Régis Dericquebourg, «Maïté Maskens, Cheminer avec Dieu : pentecôtisme et migrations à Bruxelles », Archives de sciences sociales des religions [En ligne], 168 | 2014, mis en ligne le 11 mai 2015, consulté le 22 septembre 2020. URL : http://journals.openedition.org/assr/26497 ; DOI : https:// doi.org/10.4000/assr.26497

Ce document a été généré automatiquement le 22 septembre 2020.

() Archives de sciences sociales des religions 


\section{Maïté Maskens, Cheminer avec Dieu : pentecôtisme et migrations à Bruxelles}

Bruxelles, Éditions de l'Université de Bruxelles, coll. « Religion, laïcité et société », 2013, 220 p.

Régis Dericquebourg

\section{RÉFÉRENCE}

Maïté Maskens

Maïté Maskens, Cheminer avec Dieu : pentecôtisme et migrations à Bruxelles, Bruxelles, Éditions de l'Université de Bruxelles, coll. « Religion, laïcité et société », 2013, 220 p. 
1 Ce livre est issu d'une thèse soutenue à l'ULB. L'auteur relate une recherche conduite dans les Églises Évangéliques de Bruxelles fréquentées par des immigrés. La thèse s'inscrit donc dans les recherches sur l'attrait qu'exercent des groupes religieux minoritaires sur les populations en situation interculturelle. Elle s'appuie sur une observation participante avouée dont l'auteur a le mérite de rappeler une fois de plus l'intérêt et la difficulté sur le plan méthodologique et sur le plan émotionnel (transférentiel dans le vocabulaire freudien). La thèse aboutit à plusieurs constatations. D'abord, elle met en évidence une bipolarité du pentecôtisme de l'immigration: l'affirmation d'un universalisme chrétien

Cheminer avec Dieu : pentecôtismes et migrations à Bruxelles vacheves

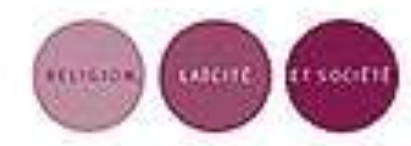
et le regroupement dans des assemblées autour d'un particularisme des origines. Ensuite, ces mouvements se légitiment par une «théologie migratoire » reposant sur l'exemple du voyage des Hébreux vers la Terre promise et des migrations des apôtres du Christ. Comme dans ces deux cas, les immigrés pentecôtistes inscrivent leur migration dans un plan divin puisqu'elle leur a permis de se convertir puis de répandre la Bible en Belgique. Ceci leur permet de s'imaginer en porteurs d'une mission régénératrice de la Belgique qui inverse le flux des missions religieuses occidentales du passé vers les colonies. Les fidèles se sont donc trouvés un rôle valorisant dans un contexte politique qui ne leur est pas favorable, où une partie des dirigeants visent leur retour dans leur pays d'origine. Paradoxalement, les pentecôtistes issus de l'immigration deviennent actifs dans la société alors qu'ils sont accusés de favoriser les particularismes par des politiciens extrémistes dont le modèle de la citoyenneté est comme en France uniformisateur. L'accusation est d'autant plus surprenante que la Belgique cultive des particularismes wallons, flamands, bruxellois qui cohabitent. Au plan psychologique, les fidèles pris dans un entre-deux culturel difficile à vivre trouvent un soutien constant dans l'Esprit Saint qu'ils invoquent toujours y compris dans les moindres activités quotidiennes. Enfin l'auteur remarque un phénomène que j'ai mis en évidence chez les Témoins de Jéhovah: la contestation versus l'adaptation. Une protestation radicale en discours contre la société peut coexister avec une vie conformiste.

2 Maïté Maskens exprime une intention comparative. En fait elle compare des communautés pentecôtistes entre elles. Or les courants évangéliques ne sont pas les seuls à recruter parmi les immigrés. Les Témoins de Jéhovah y prennent leur part et cela a été souvent étudié y compris en Belgique (Johan Leman). On peut aussi citer les mormons. Généralement, ce sont d'anciens catholiques. Dès lors, le problème posé est celui de l'attrait des migrants pour des groupes religieux minoritaires plutôt que pour des Églises établies. Quels sont les motifs de l'adhésion à une secte ou à une dénomination plutôt qu'à une autre ? On peut aussi se demander pourquoi la migration 
n'aboutit pas à l'abandon de toute affiliation religieuse dans une terre d'accueil moderne et sécularisée qui ne valorise plus l'engagement religieux intense. 